\title{
Laboratory and field measurements of body composition
}

\author{
NG Norgan * \\ Department of Human Sciences, Loughborough University, Loughborough, LE 11 3TU, UK
}

\begin{abstract}
Objective: This background paper was prepared in response to a request to review the concepts related to measurement of body composition, to discuss laboratory and field methods of assessing body composition and to discuss the practical applications of the methods - how they might be used singly or in combination to provide data for a selected population.

Design: The common laboratory and field methods are described and discussed, with particular attention to the assumptions involved and the applicability of the methods to the different population groups. Most measurements of body composition are made in the field, at the bedside or clinic as opposed to in the laboratory. The laboratory methods have a role to play in their own right, in research into new concepts, models and methods. However, they are particularly important in establishing the accuracy of the field methods.

Setting: Field, bedside and laboratory studies.

Subjects: Children, adults, the elderly, ethnic groups.

Results: Laboratory estimates of body compositions are best performed by multicomponent methods or by 2-component methods adjusted for to the populations under investigation. There is a scarcity of data for most of the populations in the world.

Conclusions: Energy requirements based on body weight are an approximation since they do not take into account differences in body composition, which will better determine the true requirements. The measurement of body composition occurs in many branches of biology and medicine. It is used in the assessment of nutritional and growth status and in disease states and their treatment. Energy stores, skeletal muscle and protein content can be determined and changes monitored. In human energetics, body composition is widely used for the standardisation of other variables, such as basal metabolic rate (BMR), in the assessments of ethnic and environmental differences and of variability and adaptation to different levels of nutrition. Choosing a method is very problematic. Users want simple, inexpensive, rapid, safe accurate methods to measure body composition but speed and simplicity come at the expense of accuracy. Recommendations are made for age, sex, and in some cases, fatness and ethnic specific methods.
\end{abstract}

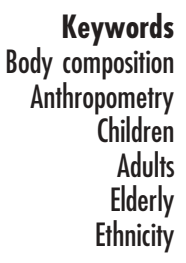

\section{Models and concepts in body composition}

'Any student of body composition must master terminology and the concepts of validation scales for assessing the effectiveness of new methods, new methods to assess regional as well as total body composition, and the need for population specific equations. Lack of understanding these concepts has hindered the development of the field. ${ }^{1}$

It is true to say that how we have viewed the body has been determined by the methods that have been available. If we can measure one component of body composition such as fat mass (FM), we can describe the body in terms of a 2-component model (2-C model) of FM and fat free mass (FFM). This was the earliest attempt at describing in vivo body composition and is still the most common method today. Similarly, if we can measure total body water (TBW) we can describe the body in terms of body water and dry matter. If the water content of FFM is regarded as constant and FM is anhydrous, the measurement of TBW can be used to derive FFM and FM. Alternatively, we can regard the body as a 3-component (3-C model) made up of FM, TBW and dry FFM (mainly protein and minerals). If we add a third measurement, e.g. of mineral content (M) or of protein total body protein (TBP), we can view the body as a 4-component model (4-C model), FM, and the constituents of FFM, namely TBW, $M$ and TBP. (The small amounts of carbohydrate and vitamins are ignored for these purposes). All of these in vivo measurements rest on certain assumptions. 
The assumption of a constant composition of FFM is central to the 2-C model and methods. As more components are measured in 3- and 4-C models and methods, fewer assumptions are required and these are regarded as superior to $2-\mathrm{C}$ methods. However, they are more difficult to perform, in terms of costs and expertise. They are normally used in a clinical setting but have an important role in the study of healthy body composition by validating simpler methods. Wang and colleagues have taken the novel and stimulating approach of considering body composition at various levels, atomic, molecular, cellular, tissue and whole body ${ }^{2,3}$. This has clarified thinking, dispelled a number of misconceptions and identified a number of gaps in knowledge and hence new research areas. However, it achieves a level of detail beyond the practical needs of most users.

The methods available for the measurement of body composition are shown in Table 1 . The majority of these are laboratory methods, or are expensive or require competent technical expertise. The most commonly used are the 2-C techniques of densitometry and hydrometry. The most commonly used field techniques are skinfold thickness and bio-impedance analysis, although the body

Table 1 Methods of measurement of body composition

\begin{tabular}{l}
\hline In vitro \\
Anatomical dissection: muscle, skeleton, adipose tissue, \\
viscera \\
Chemical analysis: water, fat, protein, mineral, carbohydrate \\
In vivo \\
Whole body \\
Densitometry \\
Hydrometry \\
Element analysis; K, Ca, N, C by in vivo neutron \\
activation analysis \\
Dual energy radiography (DER), e.g. dual energy X-ray \\
absorptiometry (DEXA) \\
Magnetic resonance imaging (MRI) \\
Regional \\
Thicknesses \\
Skinfolds, subcutaneous adipose tissue \\
Ultrasound (A-mode), computed tomography (CT) \\
DER, DEXA \\
MRI \\
Areas \\
Skinfolds + circumferences \\
Ultrasound (B mode), \\
CT, DER, MRI \\
Volumes and masses \\
Areas + lengths + densities \\
Estimations \\
Regional measurements for estimating whole body \\
composition \\
skinfold thickness \\
near infra-red interactance (NIRI) \\
Whole body measurements for estimating whole body \\
composition \\
body mass index (BMI) \\
bioimpedance analysis (BIA) \\
body electrical conductivity (Tobec)
\end{tabular}

Laboratory methods, requiring technical support, expertise or with high equipment costs, are shown in bold. mass index (BMI) is widely used as a measure of level of fatness. The apparent simplicity, speed and cheapness of some of the field techniques have led to their popularity in an unquestioning way.

These methods are ordered into levels of validity in Table 2. This distinguishes components that are measured, from those where the component of interest is derived by transformation of a measured property of the body on the basis of various biological and technical assumptions. For example, hydrometry allows the calculation of FFM by assuming the water content to be 0.73. The imaging techniques involve the transformation of physical properties of the body used to produce the image into types of tissues and the measurement of areas and volumes. The fourth level includes techniques that estimate a component of body composition based on the calibration of the estimation technique against a transformation method. As a result, they can be regarded as doubly indirect. Much of the error of estimations arises from calibrations being less than perfect for biological and technical reasons, including error in the criterion method. There are recognised approaches to establishing estimation methods which would improve the accuracy of the technique were the approaches followed more widely. These are described later.

Body composition methodology has been well served by a number of excellent reviews over the years ${ }^{4-20}$.

\section{Body composition and the assessment of energy requirements}

'Estimates of requirements based on body weight are an approximation, since they do not take into account differences in body composition which will determine the true requirements ${ }^{21}$.

Requirements for energy have their origins in the body's need to transduce energy to live and to gain energy to grow, reproduce and lactate. The rate of transduction, what is loosely called energy expenditure, depends on body size and composition. Previous practice in assessing energy requirements has included calculating these for standard or reference individuals and adjusting for body weight. However, body weight varies in composition, and hence in energy requirement, and the adjustment procedure using ratio scaling, i.e. per $\mathrm{kg}$ body weight, overestimates the energy transduction of small individuals and underestimates that of large individuals. The most recent estimates are based on basal metabolic rates (BMR) multiplied by a factor for physical activity level ${ }^{21}$. The accurate estimate of BMR is of crucial importance and is discussed in other background papers. It has been estimated from body weight by age and sex specific estimation equations ${ }^{22}$. Questions have arisen over ethnic differences in BMR and metabolic adaptation in BEE. Body composition data are needed to determine whether they actually occur, whether they represent differences in the relative proportions of actively metabolis- 
Table 2 Levels of validation of body composition methods

\begin{tabular}{lll}
\hline Level & \multicolumn{1}{c}{ Method } & \multicolumn{1}{c}{ Approach } \\
\hline 1. Measurement & Dissection, chemical analysis & Direct \\
2. Imaging & Computed tomography & Dual energy radiography, e.g. dual energy X-ray absorptiometry \\
& Magnetic resonance imaging & \\
& Ultrasound B-mode & \\
3. Transformation & Densitometry & Indirect, involves assumptions of \\
& Hydrometry & fixed relationships \\
4. Estimation & Anthropometry & Doubly indirect, calibrated against \\
& Bio-impedance analysis & transformation methods \\
& Near infra red interactance & \\
\hline
\end{tabular}

ing tissue or organ sizes or true adaptive processes of metabolic down or up-loading.

\section{BMR, FFM and FM}

FFM has been recognised for many years as a more suitable basis than body weight or surface area for expressing BMR or resting metabolic rate (RMR). FFM is usually the best single estimator of BMR with age and sex adding only small contributions to the estimation ${ }^{23}$. It has been common to express BMR and RMR as a ratio of FFM but this is invalid as the intercept of the regression equation has, in most cases, a non-zero intercept term. FM is not metabolically inert. Garby et $a l^{24}$ calculated its specific energy expenditure to be some $25 \%$ of that of FFM but considered it explained only a small part of the variation in RMR after FFM was accounted for. Others have viewed small additional contributions of $5-8 \%$ as important.

\section{BMR and organ and tissue masses}

FFM is not a homogeneous entity. Half is made up of the metabolically active body cell mass (BCM), mainly the visceral organs, skin and skeletal muscle and the remainder is the supporting tissues, including fluids and bone. Within the BCM, organs such as brain, heart, liver and kidney are estimated to have metabolic rates 15-25 times greater than the resting rate of skeletal muscle. Thus, variations in relative proportions of the BCM, of organ to skeletal muscle proportions or of relative organ sizes could all contribute to variations in the BMR of FFM. These can now be quantified using the newer body composition imaging techniques.

The positive intercept in the relationship of BMR to FFM referred to above indicates the relationship is non-linear and is influenced by varying proportions of the components of FFM and/or of tissue specific metabolic rates. Garby and Lammert ${ }^{25}$ calculated that organ mass represented a decreasing proportion of FFM as FFM increased. The higher BMR per $\mathrm{kg}$ FFM in smaller individuals may be an artefact of ratio scaling but some of it may be due to differing composition of FFM, specifically relatively smaller amounts of skeletal muscle in smaller individuals ${ }^{26}$. A considerable part of the between subject variation in BMR can be explained by differences in the composition of $\mathrm{FFM}^{27}$. Gallagher et al. ${ }^{28}$ found that BCM was not a constant proportion of FFM but varied with age, FFM, adiposity and gender. Gallagher et al. ${ }^{29}$ found strong associations between RMR and individual or combined organ weight determined by magnetic resonance imaging (MRI) and echocardiography.

\section{BMR, FFM and ageing}

BMR falls by $1-2 \%$ per decade from the second to the seventh decade of life. This is usually attributed to falling FFM. It has been suggested that not all of the decline can be attributed to lower FFM. Poehlman et al. ${ }^{30}$ regarded decreasing aerobic capacity to be involved too. Hunter et $a l .{ }^{31}$ found that trunk lean mass, indicative of organ mass, measured by dual energy X-ray absorptiometry (DEXA) and computed tomography (CT) was relatively resistant to age related changes whereas muscle mass, particularly leg muscle mass tended to be lost. Gallagher et $a l .{ }^{32}$ used their in vivo estimation of RMR from organ size data described above and published organ tissue metabolic rates to determine if age related decreases in organ tissue mass could account for the lower RMR of the elderly. Calculated RMR was some 10\% lower than measured suggesting factors other than organ atrophy are involved.

RMR per kg FFM decreases from infancy to maturity. This too has been ascribed to changing composition of FFM, in this case an increasing proportion of relatively low metabolically active resting skeletal muscle ${ }^{26}$.

\section{Ethnic differences in BMR and REE}

There has been a debate about whether BMR or RMR are lower in indigenes of tropical areas since the last Consultation. Henry and Rees ${ }^{33}$ presented new estimation equations for peoples living in the tropics that gave BMR $8 \%$ lower than the general equations ${ }^{21}$. Earlier, Lawrence et $a l .{ }^{34}$ had concluded there was no significant difference in BMR between Scottish, Gambian and Thai women of 
similar FFM. Soares et al. ${ }^{35}$ concluded there were no differences in BMR of age and weight matched Asian Indian males, other tropical populations and North Americans. Similarly, Soares et al. $^{36}$ found no evidence for an ethnic influence on basal metabolism when comparing 18-30-year-old Indians and Caucasian Australians.

The BMR and RMR of African Americans and whites has been the subject of investigation in the context of predisposition to obesity. Wong et al. ${ }^{37}$ reported a $6 \%$ lower BMR in pubertal African American girls than in Caucasian girls after adjusting for soft tissue lean mass. Hunter et al. ${ }^{31}$ examined RMR and sleeping RMR in a small number of white and African American women. FFM, FM and regional lean tissue were also determined. The African American women had lower RMR (7.5\%). Differences persisted after adjustment for maximum oxygen uptake, activity energy expenditure, FFM and limb lean tissue mass but disappeared after adjustment for trunk lean tissue. They suggest low volumes of metabolically active organs mediate the low energy expenditure of African American women. Ten out of 15 studies in adults reviewed by Gannon et $a l{ }^{38}$ reported a lower RMR in African Americans than in Caucasians, including three that adjusted for the differing bone mineral content of FFM. Yanovski ${ }^{39}$ concluded that the preponderance of evidence now suggests that African American children have lower RMR than whites, although the magnitude of the difference is small.

In conclusion, requirements for energy depend on the absolute and relative size of the body components. The accuracy of the estimate of energy requirements would be improved by using FFM rather than body weight. However, population estimates of FFM are not yet securely based for many populations, as explained later. Equally, with increasing overweight and obesity the ability of the Schofield equations ${ }^{40}$ to estimate BMR can be assumed to be declining as they were drawn up on populations with leaner body composition. Interindividual differences in BMR would be reduced by allowing for variation in FFM and its composition.

\section{Energy stores in the body}

Utilisable energy is stored in the body as bonds between carbon atoms and between carbon and hydrogen atoms. Livesey and Elia ${ }^{41}$ have determined the metabolisable energy of endogenous protein, fat and carbohydrate to be $19.68,39.5$ and $17.5 \mathrm{MJ} \mathrm{kg}^{-1}$, respectively. Thus, if the weights of these are known, the total body energy content can be calculated. The energy contents of a $70 \mathrm{~kg}$ man, BMI $23 \mathrm{~kg} \mathrm{~m}^{-2}$ and $14 \%$ fat and a $57 \mathrm{~kg}$ woman, BMI $21 \mathrm{~kg} \mathrm{~m}^{-2}$ and $26 \%$ fat are shown in Table 3 . Most of the energy in the body is stored as triacylglycerol in adipose tissue. There are substantial amounts of protein in the body but only some $50 \%$ is available as an energy source.
Table 3 Energy content of a $70 \mathrm{~kg}$ man and $57 \mathrm{~kg}$ woman

\begin{tabular}{llrlrr}
\hline & \multicolumn{2}{c}{ Man } & & \multicolumn{2}{c}{ Woman } \\
\cline { 2 - 3 } \cline { 5 - 6 } & $\mathrm{kg}$ & $\mathrm{MJ}$ & & $\mathrm{kg}$ & $\mathrm{MJ}$ \\
\hline Glycogen & 0.5 & 8 & 0.5 & 8 \\
Protein & 12 & 204 & & 10 & 170 \\
Fat & 10 & 370 & & 15 & 555 \\
Total & & 582 & & 733 \\
\hline
\end{tabular}

Thus, measurement of FM by, for example, densitometry has been a traditional method for measuring body energy content. However, methods to measure total energy content to include fat, protein and glycogen from body mass, TBW by isotope dilution space and body minerals have been derived ${ }^{42}$.

\section{Laboratory measurements of body composition}

\section{Densitometry}

The application of densitometry to the measurement of human body composition is based on the principle that if the body is regarded as being made up of two components of known densities then the body density is determined by the relative proportions of the two components. The two components are usually fat FM and FFM. Their densities are derived from animal studies, cadaver analyses and studies of the individual constituents. The most widely accepted values are those derived by $\operatorname{Siri}^{43}$.

Body density is given by mass divided volume. The determination of the volume of the irregularly shaped human body is the difficulty of the measurement. This has traditionally been measured by underwater weighing using the principle that the loss of weight underwater is equal to the weight of water displaced from which the volume of water displaced by the body can be calculated. The volume of air in the lungs during submersion must be determined and subtracted from the apparent body volume. Full experimental details have been given ${ }^{44}$ but the precise details vary from system to system ${ }^{12,45}$. The measurement of body density by underwater weighing is highly repeatable such that the precision is equal to $0.7 \mathrm{~kg} \mathrm{fat}{ }^{10}$. In this respect it outperforms many other techniques.

Not everyone can perform the manoeuvres necessary for underwater weighing. There is now an air displacement plethysmographic apparatus (BOD POD ${ }^{\mathrm{TM}}$ ) available which does not require immersion ${ }^{46}$. Measurement artefacts are a potential source of error and a tight fitting swimsuit and cap should be worn and facial hair kept to a minimum ${ }^{47,48}$. The technique may produce small underestimates of fatness, and aberrant values, probably due to variations in movement or breathing patterns, remain a problem $^{49}$. Perhaps the biggest source of error comes from the need to estimate body surface area and the use of the much criticised Du Bois and Du Bois equation ${ }^{50}$. 
The FFM is made up of water, minerals and protein. The assumption that they always exist in constant proportions so that the density of FFM is constant is not always true. Equally, it is not seriously violated in most healthy individuals. Uncertainty about hydration or bone mineralisation could theoretically introduce an error of 3-4\% in predicting body fat. The largest contribution to the error of estimating \% fat from density arises from the variability of the water content. A $1 \%$ change in body water, a tolerable level of dehydration, causes an apparent difference of $0.7 \%$ fat units. However, densitometry is usually regarded as the best 2-component laboratory technique for adults. Fogelholm and Marken ${ }^{51}$ performed a meta-analysis of 54 papers published between 1985 and 1996 comparing density with other methods. The differences observed varied in the different studies. If a less demanding technique is required hydrometry is a suitable and widely used alternative.

\section{Hydrometry}

If FFM can be assumed to have a constant proportion of water, a measure of TBW will assess FFM and, by difference, FM. TBW can be measured by the dilution of an isotopic tracer such as the stable non-radioactive isotope of hydrogen, deuterium ${ }^{52}$. Other isotopes have drawbacks, tritium is radioactive and $\mathrm{H}_{2}^{18} \mathrm{O}$ is very expensive. The dilution concentrations in urine, blood or saliva allow TBW to be calculated. However, the hydration of FFM is not constant and biological variation $(2 \%)$ can lead to an error of $3.6 \%$ fat points ${ }^{12}$. Also, exchange of the isotope with non-aqueous hydrogen leads to an overestimation of TBW of $1-5 \%$. The analytical standard error is some 1 litre equivalent to $1.4 \mathrm{~kg}$ FFM and FM.

Using doubly labelled water, measurements can be made of body composition and of total daily energy expenditure (TDEE) at the same time. Although the analysis requires a well-founded laboratory, the method can be run in the field. One drawback of the method as a field technique is the 3-5hour period necessary for dilution and equilibration of the tracer. There is also a requirement, as with most other methods, that the subjects be normally hydrated. These may be a consideration in many field circumstances.

\section{DEXA}

This is a relatively new whole body and regional body composition technique that is being used increasingly in medicine and biology. It allows the body to be described as a 3-component model of mineral, mineral free soft tissue and FM. The principle of the method is that soft tissue and bone attenuate X-rays to differing degrees. The original use of the soft tissue data was to correct for attenuation and to improve the precision of bone measurement but dual energy $\mathrm{x}$-ray absorptiometry (DEXA) has been developed for adipose and non-osseous lean tissue. Precisions of bone measurement of $1 \%$ and of soft tissue of $2-3 \%$ have been reported ${ }^{12}$. This high level of precision distinguishes DEXA from most other techniques. However, the accuracy of the method, particularly for FM is not well established ${ }^{53}$. Debate continues about the status of DEXA as a 'gold standard' criterion method ${ }^{54-56}$. Jebb ${ }^{55}$ concluded that few machines are sold for their capacity to measure soft tissue.

The advantages of DEXA is that it is relatively quick, 10$15 \mathrm{~min}$ for a total body scan, and that the radiation doses are low, $<5$ millirem (mrem). The disadvantages are that the method is not free from assumptions about hydration, but is much less affected than other methods, and the proportion of protein to water. DEXA cannot clearly distinguish between soft tissue and bone in all regions of the body and the scanner may not accommodate large individuals. Different manufacturers use different forms of calibration, software upgrades have been frequent requiring reanalysis of data and the machines of different manufacturers cannot be used interchangeably. There are also reports of differences between machines from the same manufacturers ${ }^{55}$.

\section{CT and MRI}

CT involves X-ray radiation doses at higher levels than DEXA and, as a consequence, does not have the same widespread use. X-ray sources and detectors are located on a circular gantry. A number of exposures are made and complex reconstructive software is used to generate crosssectional areas and volumes and masses of tissues. The method has been validated using phantoms of known composition or by comparison with other methods such as densitometry ${ }^{57}$.

MRI utilises the property of elements with unpaired protons or neutrons, such as hydrogen and carbon, to resonate and dissipate energy after exposure to a magnetic field. The energy released is used to build up images of cross-sectional areas. No radiation is produced and so the method can be used for repeated measurements and for children. The coefficient of variation of repeated measurements of percentage fat is some $5 \% \%^{58}$. The disadvantages of MRI are the expense of the apparatus and measurement and the long scan time, 10-15 minutes, during which time the subject must remain still. However, MRI is now much faster and is a method of choice for calibration of field methods designed to measure body fat and skeletal muscle in vivo ${ }^{59}$.

Much of the current interest in laboratory based body composition research is in developing regional or tissue specific methods ${ }^{60-62}$. Imaging methods, CT MRI and DEXA, are proving useful in regional measures of body composition important in nutritional status such as muscle mass and abdominal adipose tissue deposits ${ }^{58,63,64}$.

The techniques of total body electrical conductivity and ultrasound listed in Table 1 are not considered further in this paper. For reviews see Baumgartner ${ }^{65}$ and Ramirez ${ }^{66}$. 


\section{Field methods}

\begin{abstract}
Antbropometry
Body weight

Body weight is more a dimension of size than composition but it has an important role in the assessment of nutritional status in children and adults, usually as a function of height as described below. The most variable component of the body is the FM, so body weight or weight changes are proxies for energy stores or changes in them. Level of hydration and the presence of oedema may affect body weight and its changes as indicators of energy stores. Dayto-day variations in weight of $0.5 \mathrm{~kg}$ or more occur in $32 \%$ of measurements of normally nourished men ${ }^{67}$. These reflect variation in hydration, specifically the glycogenwater pool. Although body weight may be the cardinal anthropometric measurement in the assessment of nutritional status, all of its uses in the area of body composition can be performed better by other measurements. Indeed, a major stimulus to the field of body composition was the unsatisfactory performance of body weight and weight-height indices in assessing energy stores and obesity.
\end{abstract}

\section{$B M I$}

The rationale for the BMI $\left(\mathrm{kg} \mathrm{m}^{-2}\right)$ and other weightheight indices is that weight would be a better indicator of FM and energy stores if an allowance were made for height, the second dimension of body size. In the case of BMI, weight is divided by height squared. BMI has been adopted widely as a measure of obesity, energy stores and energy undernutrition ${ }^{68,69}$. Yet the interpretation of BMI is not straightforward. It is a vector of several effects. It is a better measure of fat content, (FM kg), than of fatness, (\% fat), as might be anticipated. It is almost as much a measure of leanness, (FFM), as of fatness, ( $\%$ fat). Its relationships with body composition components differ with age, sex, and ethnicity and with body shape $e^{70-74}$.

\section{Mid upper arm circumference (MUAC)}

MUAC is an established index of nutritional status in children and hospital patients. MUAC is highly correlated with BMI and in many instances it may replace BMI as a measure of chronic energy deficiency (CED) ${ }^{75}$. This obviates the need for body weight scales and height measuring apparatus. MUAC used in conjunction with BMI refines the categorisation of CED. Transformation of MUAC to cross-sectional areas of adipose tissue and muscle plus bone do not add much to the information from MUAC alone presumably because of technical aspects of the required skinfold measurement and the assumptions about the circularity of the upper arm. Other body circumferences are used as indicators of fat distribution, particularly abdominal fat distribution, e.g. waist-to-hip ratio.

\section{Skinfold thickness}

Skinfold thickness has most of the characteristics of a good field method. The measurement is simple and quick, the callipers are inexpensive and portable and good reference data exists. Skinfolds are generally regarded as of low precision but proper training and continuous quality control prove the method to be acceptable ${ }^{76}$. Heyward and Stolarczyk ${ }^{15}$ and Heyward ${ }^{77}$ give good practical recommendations.

There is much to be said for interpreting skinfolds themselves by comparison with reference data. However, their use in estimation equations to derive whole body fatness has proved virtually irresistible. Estimation equations have been derived by relating skinfolds to a laboratory measure of body composition, usually a 2-C model such as densitometry. Estimation equations have until recently been almost always specific to the population on which they have been drawn up. Specificity has biological origins, such as age, sex, and ethnicity, and technical origins $^{78}$. The former are difficult to diminish but the latter that arise from technical and measurement factors and statistical considerations can be reduced or controlled by following the principles listed in Table 4 . This table can also be used in the selection of an estimation equation by considering which of the equations available closely fit the criteria. Lohman ${ }^{1}$ has proposed standards for evaluating estimation errors (SEE) for \% fat, FFM and FM. The same principles apply to all estimation techniques ${ }^{79}$. However, in the case of bioimpedance analysis (BIA; see later), commercial confidentiality prevents much of the required information being available. Few body composition or estimation techniques have been put through the testing procedures listed in Table 4. Some have become established through practice. The equations of Durnin and Womersley $^{80}$ for estimating body density and \% fat from skinfold thickness based on large numbers of subjects have been found to be some of the most widely applicable estimation equations.

Table 4 The validation characteristics of reliable estimation equations

1. The data from large numbers of subjects were used to derive the equations, more than 30 subjects per estimator variable.

2. Biologically appropriate independent variables were selected by robust regression procedures and not by stepwise regression alone. The relationship was tested for curvilinearity.

3. The standard error of estimate (SEE) was given more consideration than the correlation coefficient.

4. The derived equation(s) was validated internally on a separate subsample and have been validated externally on other populations.

5. A multi-component method was used to measure the criterion (dependent) variable or more than one 2-C method has been used.

6. Reliability studies have estimated the sources and magnitude of variation due to trial, time of day, exercise, diet, menstrual cycle, and other factors.

7. Interlaboratory studies with the same subjects and methodologies have shown no difference due to site. 
Skinfold thickness estimation equations have their faults but stand up well to scrutiny compared with other field techniques. They have proved to be as good as 3-C models and DEXA in estimating group mean fatness and the best of the field techniques for individual estimates of fatness ${ }^{81}$.

\section{BIA}

BIA has gained wide acceptance as a field and bedside body composition technique. This is related more to its ease of use and acceptability of the technique and less to an obvious superiority to other field methods. It is quick, simple to use and involves minimum contact with the subject or undressing. BIA has better reproducibility than skinfolds, which makes it more suitable for large studies with multiple measurers. It has proven reliability in interlaboratory comparisons ${ }^{82,83}$. The procedure has become simpler and faster still with the development of analysers that require only that the subject stand bare footed on metal plates that contain the electrodes. The need for a measurement couch, for the careful placement of wrist and ankle electrodes and the separate measurement of body weight are overcome ${ }^{84}$.

The literature on BIA is now vast and has been the subject of many critical reviews ${ }^{11-20}$. The deliberations and outcomes of a 1994 US National Institutes of Health Technology Assessment Conference 'to provide physicians with responsible assessment of bioelectrical impedance analysis (BIA) technology for body composition measurement' have been published ${ }^{85}$. An update has also appeared ${ }^{86}$. Age and sex specific reference data for FFM and FM from over 3390, 15-64-year-olds have been published ${ }^{87}$.

The principle of the method is that the resistance or impedance to the flow of a weak alternating electric current $(800 \mu \mathrm{A} 50 \mathrm{kHz})$ from two source electrodes carefully located at the wrist and detected at the ankle is inversely proportional to the total body weight (TBW). This enables TBW, FFM and hence FM to be calculated. Multifrequency instruments can estimate intracellular (ICW) and extracellular water (ECW) ${ }^{88,89}$. The frequency determines whether the current flows mainly through ECW or also penetrates cell membranes into ICW. The theory is that the body is a simple cylinder of known length and cross-sectional area, that water and electrolytes are uniformly distributed and that body temperature is constant. These are rarely true and in practice measurements of impedance and reactance are related to TBW by statistical association rather than biophysical principles. The estimation equations used include anthropometric variables such as height and weight to reflect the geometry of the body. There has been much debate about the relative contributions of height and weight and the electrical properties of the body to the estimate.

In the past, the analysers of different manufacturers and even machines from the same manufacturer have been found to perform differently. A single estimation equation cannot be expected to be valid for all subjects. If appropriate well-validated estimation equations are not available, investigators may have to develop their own. This is not an insignificant undertaking and should follow the validation procedures outlined in Table 4 . However, Kyle et al..$^{90}$ have recently published a single doubly crossvalidated for adults of both sexes and all ages with a SEE of $1.7 \mathrm{~kg}$ FFM. This needs to be considered further.

As a measure of body composition, BIA is affected by a number of influences such that it is advisable to standardise measurement conditions to an overnight fast, $24 \mathrm{~h}$ without exercise or alcohol and normal levels of hydration ${ }^{85}$. Such conditions are rather restrictive for a field method and are often, mistakenly, overlooked. Heyward and Stolarczyk ${ }^{15}$ and Heyward ${ }^{77}$ provide detailed recommended procedures for investigators and measurement technicians. As with all estimation procedures, BIA performs less well at the ends of the ranges, underestimating fatness in the obese and overestimating it in the lean. Fatness specific estimation equations with lower SEE than general equations have been drawn up ${ }^{82}$. These have been shown to be generalisable over sex, age, ethnicity and fatness. The need to establish the fat range of the subjects can be overcome by an initial averaging procedure $^{91}$.

BIA can also be applied to the measurement of the composition of segments of the body, usually the upper and lower limbs ${ }^{92,93}$. Upper and lower limb skeletal muscle mass (SM) have been measured ${ }^{94-96}$.

$\mathrm{SM}$ is a more useful body composition component for nutritional studies than FFM. It has more obvious direct links with protein nutrition and functionality than FFM, which includes water and minerals in addition to protein. Movement, balance and leg bone mass are all partially dependent on lower limb SM. Equally, upper limb SM is very important for many everyday tasks. Methods for the anthropometric estimation of total body $\mathrm{SM}^{61}$ and BIA estimation $^{97}$ have been validated against MRI. However, the imaging techniques of MRI, CT and DEXA have permitted wider studies of SM biology ${ }^{62,98}$.

\section{Children and the elderly}

Children are chemically immature until late adolescence. Their FFM is more hydrated and less mineralised than that of adults. Most adult body composition methods would overestimate fatness of children. This must be taken into account when calculating body composition from densitometry and hydrometry. Estimation equations allowing for these differences are available and have been used widely (see Appendix I).

The hydration of FFM decreases in the elderly too but so does the mineralisation by approximately $1 \%$ per year between 50 and 70 years. However, there is considerable interindividual variation in the elderly, particularly in 
extreme old age. The net result may be that the density of FFM is unaltered. Sarcopenia is a common occurrence with ageing and the loss will also change the composition of FFM. 3-C and 4-C methods may be required and are usually recommended in the elderly. There are, however, a few cross-validated estimation equations that have used a multicomponent method as the criterion method. Recommended field techniques are listed in Appendix I.

\section{Changes in body composition: their measurement and their effects on the measurement of body composition}

In much of nutrition and medicine investigators are interested in changes in body composition as much as in absolute values. However, the ability of most methods to measure change is less than the measurement of absolute values. Part of the problem is that changes may violate the assumptions on which the methods are based. For example, decreases in mineral or muscle tend to result in underestimation of fatness by 2-component methods and decreases in water tend to overestimate. A further difficulty in assessing the effects of variable composition is that most of the work has been performed on the obese undergoing reduction or on intravenous feeding.

Jebb et al. ${ }^{99}$ compared the ability of a number of techniques to measure changes in body composition during experimental under and overfeeding compared with fat balance. A 3-component method based on density and hydrometry had the least bias and greatest precision (lowest SD of the differences). They suggested that the smallest change in fat that could be measured was $1.5 \mathrm{~kg}$. Their results show that two field methods of BMI and skinfolds had better biases and so would be better for estimating group mean changes. They were less successful at measuring individual changes. Much attention has been given to the field methods for measuring changes, particularly BIA. By way of a summary, Forbes et al. ${ }^{100}$ combined the results of seven studies and concluded that weight change was a more reliable predictor of FFM change than impedance change.

\section{Ethnic differences in body composition relevant to methodology}

Ethnic differences in body composition in relation to energy metabolism and disease have been a hot topic in body composition research recently. However, in the following discussion the issues are not ethnic differences in fatness or fat distribution and disease but whether ethnic differences in body composition invalidate the assumptions that underpin all in vivo methods. For example, does the hydration of FFM differ in different population groups thus invalidating hydrometry and densitometry? Do regional differences in subcutaneous adipose tissue distribution or body configuration invalidate the estimates of body composition from skinfolds and BIA, respectively? The field is new enough in terms of the volume of work performed not yet to have had to face the problem of considerably divergent and contradictory findings. These can be expected to arise not least out of the poorly defined terminology that has been used.

There is agreement that ethnicity is based on cultural and behavioural factors and the current view is that it is the term of choice. Race is the term applied to a mixture of physical features such as skin colour arising from genetic factors. A problem with ethnicity is that it is not easily measured or amenable to concise description. It is imprecise and fluid and often a matter of selfperception ${ }^{101}$. Often broad categories are used that cover a wide range of cultural and behavioural aspects, including food and nutrition, and particularly economic status. Groupings based on geographical areas are similarly flawed. The problem with race is that supposed races are far from homogeneous, all having varying degrees of genetic admixture such that race is a continuous variable not a discrete variable. Also, supposed racial differences, such as relative limb lengths have wide intra-group variability and may show changes with time. Race has become a discredited concept, largely rejected in anthropology. But ethnicity and race are integral to modern epidemiology and public health and the concept of race is being reconsidered ${ }^{102}$. McKenzie and Crowcroft ${ }^{103}$ in an editorial in the British Medical Journal recommend that terminology should reflect the hypotheses or mechanisms under investigation. If it is thought that differences in, for example, the relative organ size or the relative leg lengths are important these might better be described as racial then ethnic differences.

The other problem with terminology in this area is that it is usually poorly defined or not defined at all in publications. It is most important that reports contain sufficient details to ensure that comparisons with other groups either in their differences or in their similarities are valid. Describing the groups fully is better than trying to find a catch-all name ${ }^{104}$. Body composition studies rarely have randomly selected subjects but self-selected subjects from an Indian university may be very different from those of an English university in factors other than ethnicity. In the following discussion, the terminology of the original authors has been retained as there is usually no information on which to make a more precise description.

\section{Ethnic and racial differences in body composition}

Much of the work on ethnic and racial differences in body composition relevant to the external validity of the methods has been on North Americans, African Americans (blacks) and Caucasians (whites). It has been known for 
some time that blacks have, on average, greater bone mineral densities and body protein content, have differences in distribution of subcutaneous adipose tissue and the length of limbs relative to trunk ${ }^{105}$. Thus, blacks will have, on average, a higher density of FFM which means that the classical 2-C equations for converting body density to body fat will underestimate fatness ${ }^{106}$. However, this is not a universal finding ${ }^{107}$. Significant differences in composition of FFM have also been reported between Dutch Caucasians and Singapore Chinese $^{108}$ and among Singapore Chinese, Malays and Indians ${ }^{109}$.

TBW makes up the largest part of FFM but the literature indicates no significant differences in TBW relative to FFM determined by the appropriate techniques. Minerals make up a much smaller proportion but because they are three times as dense as water variability could affect density of FFM. Wagner and Heyward ${ }^{105}$ in their recent comprehensive review concluded that the skeletons of blacks are heavier than those of whites throughout the life span and that bone mineral content and densities were greater too. The aetiology of these racial differences in bone is unknown but not without a wide variety of proposed mechanisms. The estimate of higher protein content in FFM of blacks is based on four reports, two of which are on adolescents. It is now generally agreed that allowance for a higher density of FFM than that in 2-C models based on data from whites should be made when converting body density measurements to fatness. Where feasible, multicomponent methods should be used.

Blacks also tend to have higher ratios of trunk to extremity skinfolds, usually evinced as a smaller triceps to subscapular skinfold. They may also have a tendency towards more subcutaneous fat on the upper than the lower trunk compared to whites, as evinced by comparisons of subscapular to supra iliac skinfolds. Differences in the distribution of abdominal adipose tissue have been reported but this is not relevant to this discussion.

Norgan $^{110}$ reviewed the available data on the generalisability of field methods drawn up on Europeans and European origin groups to population groups in developing countries. The equations of Durnin and Womersley ${ }^{80}$ provided accurate assessments of group mean body fatness in half the 20 studies reviewed. Other equations were less applicable. BIA consistently yielded measures of body composition significantly different to those of densitometry and hydrometry in blacks and Guatemalans. This may be explained in part by differing shapes in these groups compared to whites, particularly variations in relative limb lengths which have disproportionate effects on impedance and reactance. The following paragraphs in this section update the earlier review of Norgan ${ }^{110}$ on the effects of ethnic differences on the applicability of field methods of body composition.

\section{Ethnic differences in the relationship of BMI to body composition}

BMI may not be an entirely satisfactory index of body composition but it is well established as an indicator of energy stores in under and overweight. The evidence from developing countries for differences in body composition in relation to BMI has been reviewed ${ }^{72}$. Comparisons were made of the regressions of \% fat, FFM and FM on BMI in African, Asian, Indo-Mediterranean but not Europeans, and Pacific peoples based on a description of site location. There were no differences in regression coefficients of $\%$ fat on BMI in women of the four groups and of FFM in men. In all other cases, differences were statistically significant. The analyses had several significant weaknesses, particularly the use of 2-C body composition methods or estimation equations drawn up on Europeans, and in some cases the calculation of BMI and skinfold thickness from mean values of the individual measurements. The potential importance of relative leg length to the interpretation of BMI was stressed but with a reminder that intra-group variation in this characteristic could be as high as inter-group variation.

Gallagher et ll $^{73}$ using a $4-\mathrm{C}$ model found no effect of ethnicity in US blacks and whites on BMI-body fat relationships, after controlling for age and sex. Deurenberg et al. ${ }^{111}$ also found no difference in the relationships between Dutch and Beijing Chinese. However, these reports are the exceptions and even differences between European and American Caucasians have been reported ${ }^{112}$. Wang et al. ${ }^{113}$ found US Asians had lower BMI than whites but were fatter, had more subcutaneous fat and different fat distributions. Differences were greater in women than in men. Luke et al. ${ }^{114}$ used BIA to examine the ability of BMI to predict body fat in populations of West African origin living in Nigeria, Jamaica and the US. Regression coefficients did not differ across populations but intercept terms did indicating different levels of fatness at a given BMI. Rush et al. ${ }^{115}$ using hydrometry found that Polynesian women had a higher BMI at a given body fat than New Zealand women. A BMI of 30 for New Zealand Europeans corresponded to a BMI of 34 in Polynesians of the same fatness.

Gurrici et al. ${ }^{116}$ using hydrometry to estimate fatness found different relationships between BMI and fatness in Dutch and Indonesians. Indonesians were $5 \%$ points fatter than the Dutch for the same weight, height, age and sex. The authors concluded that BMI cut-offs for obesity should be lower in Indonesians than those generally proposed. Gurrici et al. ${ }^{117}$ confirmed these findings and also reported differences between Malay and Chinese Indonesians. Half the differences could be ascribed to differences in relative leg length and body build. Higher levels of fatness for a given BMI have been found in groups of Singapore Chinese, Beijing Chinese and Dutch Caucasians $^{74}$ and Chinese Malays and Indians in 
Singapore ${ }^{109}$. Deurenberg et al. ${ }^{112}$ concluded from a metaanalysis that for the same level of fatness, age and sex, American blacks $\left(+1.3 \mathrm{~kg} \mathrm{~m}^{-2}\right)$ and Polynesians $(+4.5)$ had higher BMI than Caucasians. BMI was lower in Chinese ( -1.9$)$, Ethiopians ( -4.6$)$, Indonesians (-3.2) and Thais $(-2.9)$.

Gallagher et l $^{118}$ in attempting to develop guidelines for healthy percentage body fat guidelines based on BMI found that ethnic differences between whites, African Americans and Japanese decreased with age but increased with BMI.

Thus, a given BMI represents considerably different fat contents in different population groups. The findings appear persuasive arguments for considering different BMI levels to define underweight and overweight in different population groups. However, BMI cut-offs for underweight and overweight are based more on functional outcomes than on particular levels of body composition.

\section{Ethnic differences in the relation of skinfolds to body composition}

Norgan ${ }^{110}$ reported that the equations of Durnin and Womersley ${ }^{80}$ provided accurate estimates of group mean $\%$ fat in half the 20 groups from developing countries tested. Kuriyan et al. ${ }^{119}$ using densitometry as the criterion method found no significant differences in estimates of FFM and \% fat from the equations of Durnin and Womersley ${ }^{80}$ in south Indian men and women. Deurenberg et al. ${ }^{120}$ compared $\%$ fat from the equations of Durnin and Womersley ${ }^{80}$ and $2-\mathrm{C}$ and $3-\mathrm{C}$ models in Singapore and Beijing Chinese. Bias was less than $1 \%$ and better than other anthropometric techniques and BIA. They recommend these equations but the other techniques such as BIA require the development of population specific formulae. However, Irwin et al. ${ }^{121}$ using densitometry reported that the Jackson and Pollock seven skinfold equations ${ }^{122,123}$ performed better than the equations of Durnin and Womersley ${ }^{80}$ in African American women. Brandon ${ }^{124}$ found that seven commonly used equations gave better estimations in US white women than in African American women using densitometry and ethnic specific equations for converting body density to fatness. Wong et al. ${ }^{125}$ determined the agreement between a 4 -C model and eight skinfold estimation equations in African American adolescents. The quadratic equation of Slaughter et al. ${ }^{126}$ performed best in children and adolescents but an individual \% fat could be over or underestimated by $10 \%$. Wagner and Heyward ${ }^{105}$ concluded from their comparative review that American blacks were leaner than whites for a given skinfold thickness. This suggests they have a greater proportion of fat situated subcutaneously. Wang et al. ${ }^{127}$ in an overview of anthropometry and body composition concluded that estimation reliabilities are consistently higher for white than for other ethnic groups.

\section{Ethnic differences in the relations of BIA to body composition}

Norgan $^{110}$ reported that BIA had not proved to be applicable to populations in developing countries. There is now more work in the literature on the applicability of BIA to groups other than Caucasians. In a small number of US Hispanic women, FFM estimates from six BIA estimation equations were all significantly different from density estimates ${ }^{128}$. However, biases were less than $1 \mathrm{~kg}$ for three of the equations. Body resistance of Polynesians was lower, i.e. they were leaner, than Caucasians for a given $\mathrm{BMI}^{129}$. A similar finding was reported in Maoris and Samoans ${ }^{130}$. Using DEXA as the criterion method, estimation equations were drawn up using BIA, height, weight or skinfold thickness for prediction of body composition in Polynesians. Heitman et al. ${ }^{131}$ found a constant relationship between impedance and body weight in Caucasians, Melanesians and Polynesians but not Australian Aborigines. BIA estimates of FFM in South Indians were lower and \% fat higher than values from densitometry $^{119}$. This was ascribed to the use of a manufacturer's equation derived on a Western population. An equation derived by the authors performed satisfactorily. In Chinese in Singapore and Beijing, BIA estimations from equations drawn up on Caucasians underestimated $\%$ fat by three points ${ }^{120}$. The bias increased with fatness. In 6-17-year-old US black and white girls, ethnic specific equations were found to be necessary to estimate FFM and hence \% fat for accurate estimation from BIA ${ }^{132}$. The accuracy of BIA estimates compared to DEXA in overweight African American and Caucasian women was affected by ethnicity ${ }^{133}$. FFM was overestimated by $1.2 \pm 2.8 \mathrm{~kg}$ in African Americans by a fatness specific equation ${ }^{82}$.

At least some part of the ethnic differences arises from body shape. Snijder et al. ${ }^{134}$ found that the estimation error of $\%$ fat from BIA compared with densitometry and DEXA was related to the length of the arms and legs. BIA overestimates fatness in individuals with relatively long limbs.

In conclusion, for each of the field methods considered it is preferable to use population specific estimation equations where they exist and where they have been drawn up appropriately and cross validated.

\section{Conclusions}

Requirements for energy depend on the absolute and relative size of body components. The accuracy of the estimate of energy requirements would be improved by using the FFM rather than body weight as a basis of 
reference. However, population estimates of FFM are not securely based in most populations.

The estimation of body composition in the field should be based on population specific estimation equations drawn up according to recommended validation criteria. A limited number of such equations exist for the various groups in North America and in the Far East. For many populations, such equations are not available which restricts the use of body composition data in estimating energy requirements.

Laboratory estimates of body compositions are best performed by multi-component methods or by 2-component methods adjusted for to the populations under investigation. Here too there is a scarcity of data for most of the populations in the world.

Thus, more research is needed on these basic issues. In performing such research, it is important that the characteristics of the population are fully described and overly simplistic terminology avoided.

\section{References}

1 Lohman TG. Advances in Body Composition Assessment. Champaign, Illinois: Human Kinetics Publications, 1992.

2 Wang ZM, Pierson RN, Heymsfield SB. The five-level model: a new approach to organizing body-composition research. American Journal of Clinical Nutrition 1992; 56 $19-28$.

3 Wang ZM, Heshka S, Pierson RN, Heymsfield SB. Systematic organization of body-composition methodology: an overview with emphasis on component-based methods. American Journal of Clinical Nutrition 1995; 61: 457-65.

4 Keys A, Brozek J. Body fat in adult man. Physiological Reviews 1953; 33: 245-345.

5 Brozek J. Body composition parts I and II. Annals of the New York Academy of Sciences 1963; 110: 1-1018.

6 Brozek J. Human Body Composition: Approaches and Applications. Oxford: Pergamon Press, 1965.

7 Behnke AR, Wilmore JK. Evaluation and Regulation of Body Build and Composition. Englewood Cliffs: PrenticeHall Inc, 1974.

8 Lukaski HC. Methods for the assessment of human body composition: new and traditional. American Journal of Clinical Nutrition 1987; 46: 537-56.

9 Forbes GB. Human Body Composition: Growth, Aging, Nutrition, and Activity. New York: Springer-Verlag, 1987.

10 Coward WA, Parkinson SS, Murgatroyd PR. Body composition measurements for nutrition research. Nutrition Research Reviews 1998; 1: 115-24.

11 Elia M. Body composition analysis: an evaluation of 2 component models, multicomponent models and bedside techniques. Clinical Nutrition 1992; 11: 114-27.

12 Jebb SA, Elia M. Techniques for the measurement of body composition: a practical guide. International Journal of Obesity 1993; 17: 611-21.

13 Davies PSW, Cole TJ. Body Composition Techniques in Health and Disease. Cambridge: Cambridge University Press, 1995.

14 Roche AF, Heymsfield SB, Lohman TG. Human Body Composition. Champaign, Illinois: Human Kinetics, 1996.

15 Heyward VH, Stolarczyk LM. Applied Body Composition Assessment. Champaign, Illinois: Human Kinetics, 1996.

16 Norton K, Olds T. Anthropometrica. Sydney: UNSW Press, 1966.
17 Heymsfield SB, Wang ZM, Withers RT. Multicomponent molecular level models of body composition analysis. In: Roche AF, Heymsfield SB, Lohman TG, eds. Human Body Composition. Champaign, Illinois: Human Kinetics, 1996, $129-47$.

18 Yasmura S, Wang J, Pierson RN, Jr, eds. In vivo body composition studies. Annals of the New York Academy of Sciences 2000; 904: 1-631.

19 Lohman TG, Harris M, Teixeira PJ, Weiss L. Assessing body composition and changes in body composition. Another look at dual-energy X-ray absorptiometry. Annals of the New York Academy of Sciences 2000; 904: 45-54.

20 Ellis KJ. Human body composition: in vivo methods. Physiological Reviews 2000; 80(2): 649-80.

$21 \mathrm{FAO} / \mathrm{WHO} / \mathrm{UNU}$. Energy and Protein Requirements. Geneva: World Health Organization, 1985.

22 Schofield WN, Schofield C, James WPT. Basal metabolic rate-review and prediction, together with an annotated bibliography of source material. Human Nutrition Clinical Nutrition 1985; 39C: 1-96.

23 Cunningham JJ. A reanalysis of the factors influencing basal metabolic rate in normal adults. American Journal of Clinical Nutrition 1980; 33: 2372-4.

24 Garby L, Garrow JS, Jorgensen B, Lammert O, Madsen K, Sorensen P, Webster J. Relation between energy expenditure and body composition in man: specific energy expenditure in vivo of fat and fat-free tissue. European Journal of Clinical Nutrition 1988; 42: 301-5.

25 Garby L, Lammert O. An explanation for the non-linearity of the relation between energy expenditure and fat-free mass. European Journal of Clinical Nutrition 1992; 46: $235-6$.

26 Weinsier RL, Schutz Y, Braco D. Re-examination of the relationship of resting metabolic rate to fat-free mass and to the metabolically active compartment. American Journal of Clinical Nutrition 1992; 55: 790-4.

27 Garby L, Lammert O. Between-subject variation in energy expenditure: estimation of the effect of variation in organ size. European Journal of Clinical Nutrition 1994; 48(Suppl.): 376-8.

28 Gallagher D, Visser M, Wang Z, Harris T, Pierson RN, Heymsfield SB. Metabolically active component of fat-free body mass: influence of age, adiposity, and gender. Metabolism 1996; 45: 927-92.

29 Gallagher D, Belmonte D, Deurenberg P, Wang Z, Krasnow $\mathrm{N}$, Pi-Sunyer FX, Heymsfield SB. Organ-tissue mass measurement allows modeling of REE and metabolically active tissue mass. American Journal of Physiology 1998; 275: E258.

30 Poehlman ET, Berke EM, Joseph JR, Gardener AW, Katzman-Rooks SM, Goran MI. Influence of aerobic capacity, body composition, and thyroid hormones on the age-related decline in resting metabolic rate. Metabolism 1992; 41: 915-21.

31 Hunter GR, Weinsier RL, Darnell BE, Zuckerman PA, Goran MI. Racial differences in energy expenditure and aerobic fitness in premenopausal women. American Journal of Clinical Nutrition 2000; 71: 500-6.

32 Gallagher D, Heymsfield SB, Heo M, Jebb SA, Murgatroyd PR, Sakamoto Y. Healthy percentage body fat ranges: an approach for developing guidelines based on body mass index. American Journal of Clinical Nutrition 2000; 72: 694-701.

33 Henry CJK, Rees DG. New predictive equations for the estimation of basal metabolic rate in tropical peoples. European Journal of Clinical Nutrition 1991; 45: 177-85.

34 Lawrence M, Thongprasert K, Durnin JVGA. Betweengroup differences in basal metabolic rates: an analysis of data collected in Scotland. The Gambia and Thailand. European Journal of Clinical Nutrition 1988; 42: 877-91. 
35 Soares MJ, Francis DG, Shetty PS. Predictive equations for basal metabolic rates of Indian males. European Journal of Clinical Nutrition 1993; 47: 389-94.

36 Soares MJ, Piers LS, O'Dea K, Shetty PS. No evidence for an ethnic influence on basal metabolism: an examination of data from India and Australia. British Journal of Nutrition 1998; 79: 333-41.

37 Wong WW, Butte NF, Ellis KJ, Hergenroeder AC, Hill RB, Stuff JE, Smith EO. Pubertal African-American girls expend less energy at rest and during physical activity than Caucasian girls. Journal of Clinical Endocrinology and Metabolism 1999; 84: 906-11.

38 Gannon B, Dipietro L, Poehlman ET. Do African Americans have lower energy expenditure than Caucasians? International Journal of Obesity 2000; 24: 4-13.

39 Yanovski JA. Resting energy expenditure in African American and white children. American Journal of Clinical Nutrition 2001; 73: 149-50.

40 Schofield WN. Predicting basal metabolic rate; new standards and review of previous work. Human Nutrition Clinical Nutrition 1985; 39C: 5-41.

41 Livesey G, Elia M. Estimation of energy expenditure, net carbohydrate utilization, and net fat oxidation and synthesis by indirect calorimetry: evaluation of errors with special reference to the detailed composition of fuels. American Journal of Clinical Nutrition 1988; 47: 608-28.

42 Sutcliffe JF, Knight GS, Pinilla JC, Hill JC. New and simple equations to estimate the energy and fat contents and energy density of humans in sickness and health. British Journal of Nutrition 1993; 69: 631-44.

43 Siri WE. Body composition from fluid spaces and density: analysis of methods. In: Brozek J, Henschel A, eds. Techniques for Measuring Body Composition. Washington, DC: National Academy of Sciences, National Research Council, 1961, 223-80.

44 Norgan NG. Densitometry. In: Fidanza F, ed. Nutritional Status Assessment: A Manual for Population Studies. London: Chapman and Hall, 1991, 64-70.

45 Going SB. Densitometry. In: Roche AF, Heymsfield SB, Lohman TG, eds. Human Body Composition. Champaign, Illinois: Human Kinetics, 1996, 3-23.

46 McCrory MA, Gomez TD, Bernauer EM, Mole PA. Evaluation of a new air displacement plethysmograph for measuring human body composition. Medicine and Science in Sports and Exercise 1995; 27: 1686-91.

47 Fields DA, Hunter GR, Goran MI. Validation of the BOD POD with hydrostatic weighing: influence of body clothing. International Journal of Obesity and Related Metabolic Disorders 2000; 24: 200-5.

48 Higgins PB, Fields DA, Hunter GR, Gower BA. Effect of scalp and facial hair on air displacement plethysmography estimates of percentage of body fat. Obesity Research 2001; 9: 326-30.

49 Wells JCK, Fuller NJ. Precision of measurement and body size in whole-body air-displacement plethysmography. International Journal of Obesity 2001; 25: 1161-7.

50 Du Bois D, Du Bois EF. A formula to estimate the approximate surface area if height and weight be known. Archives of Internal Medicine 1916; 17: 863-71.

51 Fogelholm M, van Marken L. Comparison of body composition methods: a literature analysis. European Journal of Clinical Nutrition 1997; 51: 495-503.

52 Schoeller DA. Hydrometry. In: Roche AF, Heymsfield SB, Lohman TG, eds. Human Body Composition. Champaign, Illinois: Human Kinetics, 1996, 25-44.

53 Lohman TG. Dual energy X-ray absorptiometry. In: Roche AF, Heymsfield SB, Lohman TG, eds. Human Body Composition. Champaign, Illinois: Human Kinetics, 1996,
63-78.
54 Roubenoff R, Kehsyias JJ, Dawson-Hughes B, Heymsfield SB. Use of dual-energy X-ray absorptiometry in body composition studies: not yet a gold standard. American Journal of Clinical Nutrition 1993; 58: 589-91.

55 Jebb SA. Measurement of soft tissue composition by dual energy X-ray absorptiometry: a review. British Journal of Nutrition 1997; 77: 151-63.

56 Modlesky CM, Evans EM, Millard-Stafford ML, Collins MA, Lewis RD, Cureton KJ. Impact of bone mineral estimates on percent fat estimates from a four-component model. Medicine and Science in Sports and Exercise 1999; 31: $1861-8$

57 Despres J-P, Ross R, Lemieux S. Imaging techniques applied to the measurement of body composition. In: Roche AF, Heymsfield SB, Lohman TG, eds. Human Body Composition. Champaign, Illinois: Human Kinetics, 1996, 149-66.

58 van der Kooy K, Seidell JC. Techniques for measurement of visceral fat: a practical guide. International Journal of Obesity 1993; 17: 187-96.

59 Ross R, Goodpaster B, Kelley D, Boeing H. Magnetic resonance imaging in human body composition research: from quantitative to qualitative tissue measurement. New York Academy of Sciences 2000; 904: 12-17.

60 Elia M, Fuller NJ, Hardingham CR, Graves M, Screaton N, Dixon AK, Ward LC. Modeling leg sections by bioelectrical impedance analysis, dual energy X-ray absorptiometry, and anthropometry: assessing skeletal muscle volume using magnetic resonance imaging as a reference. Annals of the New York Academy of Sciences 2000; 904: 298-305.

61 Lee RC, Wang Z-M, Heo M, Ross R, Janssen I, Heymsfield SB. Total body skeletal muscle mass: development and cross-validation of anthropometric prediction models. American Journal of Clinical Nutrition 2000; 72: 796-803.

62 Shih R, Wang Z, Heo M, Wang W, Heymsfield SB. Lower limb skeletal muscle mass: development of dual-energy $\mathrm{X}$-ray absorptiometry prediction model. Journal of Applied Physiology 2000; 89: 1380-6.

63 Mitsiopoulos N, Baumgartner RN, Heymsfield SB, Lyons W, Gallagher D, Ross RK. Cadaver validation of skeletal muscle measurement by magnetic resonance imaging and computerized tomography. Journal of Applied Physiology 1998; 85: $115-22$.

64 Fuller NJ, Hardingham CR, Graves M, Screaton N, Dixon AK, Ward LC, Elia M. Assessment of limb muscle and adipose tissue by dual-energy X-ray absorptiometry using magnetic resonance imaging for comparison. International Journal of Obesity 1999; 23: 1295-302.

65 Baumgartner RN. Electrical impedance and total body electrical conductivity. In: Roche AF, Heymsfield SB, Lohman TG, eds. Human Body Composition. Champaign, Illinois: Human Kinetics, 1996, 79-108.

66 Ramirez ME. Measurement of subcutaneous adipose tissue using ultrasound images. American Journal of Physical Anthropology. 1992; 89: 347-57.

67 Edholm OG, Adams JM, Best TW. Day-to-day weight changes in young men. Annals of Human Biology 1974; 1: 3-12.

68 Shetty PS, James WPT. Body Mass Index: A measure of chronic energy deficiency in adults. FAO Food and Nutrition Paper No. 56. Rome: Food and Agricultural Organization, 1994.

69 WHO. Physical Status: The Use and Interpretation of Anthropometry. WHO Technical Report Series No. 854. Geneva: World Health Organization, 1995.

70 Deurenberg P, Weststrate JA, Seidell JC. Body mass index as a measure of body fatness: age- and sex-specific prediction formulas. British Journal of Nutrition 1991; 65: 105-14.

71 Norgan NG. Body mass index and body energy stores in developing countries. European Journal of Clinical Nutrition 1990; 44: 79-84. 
72 Norgan NG. Population differences in body composition in relation to the body mass index. European Journal of Clinical Nutrition 1994; 48: S10-27.

73 Gallagher D, Visser M, Sepulveda D, Pierson RN, Harris T, Heymsfield SB. How useful is body mass index for comparison of body fatness across age, sex, and ethnic groups? American Journal of Epidemiology 1996; 143: 228-39.

74 Deurenberg P, Deurenberg-Yap M, Wang J, Lin FP, Schmidt G. The impact of body build on the relationship between body mass index and percent body fat. International Journal of Obesity 1999; 23: 537-42.

75 James WPT, Mascie-Taylor GCN, Norgan NG, Bistrian BR, Shetty PS, Ferro-Luzzi A. The value of arm circumference measurements in assessing chronic energy deficiency in third world adults. European Journal of Clinical Nutrition 1994; 48: 883-94.

76 Oppliger RA, Spray JA. Skinfold measurement variability in body density prediction. Research Quarterly in Exercise and Sports 1987; 58: 178-83.

77 Heyward VH. Practical body composition assessment for children, adults, and older adults. International Journal of Sports Nutrition 1998; 8: 285-307.

78 Norgan NG, Ferro-Luzzi A. The estimation of body density in men: Are general equations general? Annals of Human Biology 1985; 12: 1-15.

79 Guo SS, Chumlea WC. Statistical methods for the development and testing of predictive equations. In: Roche AF, Heymsfield SB, Lohman TG, eds. Human Body Composition. Champaign, Illinois: Human Kinetics, 1996, 191-202.

80 Durnin JVGA, Womersley J. Body fat assessed from total body density and its estimation from skinfold thicknesses: measurements on 481 men and women from 16 to 72 years. British Journal of Nutrition 1974; 32: $77-97$.

81 Fuller NJ, Jebb SA, Laskey MA, Coward WA, Elia M. Four component model for the assessment of body composition in humans: comparison with the alternative methods, and evaluation of density and hydration of fat-free mass. Clinical Science 1992; 82: 687-93.

82 Segal KR, Van Loan MD, Fitzgerald PI, Hodgdon JA, Van Itallie TB. Lean body mass estimation by bioelectrical impedance analysis: a four site cross-validation study. American Journal of Clinical Nutrition 1988; 47: 7-14.

83 Deurenberg P, Westerterp KR, Velhuis-Te Wierk EJM. Between-laboratory comparison of densitometry and bioelectrical impedance measurements. British Journal of Nutrition 1994; 71: 309-16.

84 Jebb SA, Cole TJ, Doman D, Murgatroyd PR, Prentice AM. Evaluation of the novel Tanita body-fat analyser to measure body composition by comparison with a fourcomponent model. British Journal of Nutrition 2000; 83: 115-22.

85 Yanovski JA, Hubbard VS, Heymsfield SB, Lukaski HC. Bioelectrical impedance analysis. American Journal of Clinical Nutrition 1996; 64: 387S-532S

86 Ellis KJ, Bell SJ, Chertow GM, Chumlea WC, Knox TA, Kotler DP, Lukaski HC, Schoeller DA. Bioelectrical impedance methods in clinical research: a follow-up to the NIH Technology Assessment Conference. Nutrition 1999; 15: 874-80.

87 Pichard C, Kyle UG, Bracco D, Slosman DO, Morabia A Schutz Y. Reference values of fat-free masses by electrical impedance analysis in 3393 health subjects. Nutrition 2000; 16: $245-54$.

88 De Lorenzo A, Andreoli A, Matthie J, Withers P. Predicting body cell mass with bioimpedance by using theoretical methods: a technological review. Journal of Applied Physiology 1997; 82: 1542-58.
89 Gudivaka R, Schoeller DA, Kushner RF, Bolt MJG. Singleand multifrequency models for bioelectrical impedance analysis of body water compartments. Journal of Applied Physiology 1999; 87: 1087-96.

90 Kyle UG, Genton L, Karsegard L, Slosman DO, Pichard C. Single prediction equation for bioelectrical impedance analysis in adults aged 20-94 years. Nutrition 2001; 17 248-53.

91 Stolarczyk LM, Heyward VH, Van LM, Hicks VL, Wilson WL, Reano LM. The fatness-specific bioelectrical impedance analysis equations of Segal et al. are they generalizable and practical? American Journal of Clinical Nutrition 1997; 66 $8-17$.

92 Chumlea WC, Baumgartner RN, Roche AF. Specific resistivity used to estimate fat-free mass from segmental body measures of bioelectric impedance. American Journal of Clinical Nutrition 1988; 48: 7-15.

93 Organ LW, Bradham GB, Gore DT, Lozier SL. Segmental bioelectrical impedance analysis: theory and application of a new technique. Journal of Applied Physiology 1994; 77 $98-112$.

94 Heymsfield SB, Gallagher D, Grammes J, Nunez C, Wang J, Pietrobelli A. Upper extremity muscle mass: potential of measurement with single frequency bioimpedance analysis. Applied radiation and Isotopes 1998; 49: 473-4.

95 Pietrobelli A, Morrison CE, Battistini N, Chiumello G, Nunez C, Heymsfield SB. Appendicular skeletal muscle mass: prediction from multiple frequency segmental bioimpedance analysis. European Journal of Clinical Nutrition 1998; 52: 507-11.

96 Nunez C, Gallagher D, Grammes J, Baumgartner RN, Ross R, Wang J, Thornton JC, Heymsfield SB. Bioimpedance analysis: potential for measuring lower limb skeletal muscle mass. Journal of Parenteral and Enteral Nutrition 1999; 23 96-103.

97 Janssen I, Heymsfield SB, Baumgartner RN, Ross R Estimation of skeletal muscle mass by bioelectrical impedance analysis. Journal of Applied Physiology 2000 89: $465-71$.

98 Lukaski HC. Estimation of muscle mass. In: Roche AF, Heymsfield SB, Lohman TG, eds. Human Body Composition. Champaign, Illinois: Human Kinetics, 1996, 109-28.

99 Jebb SA, Murgatroyd PR, Goldberg GR, Prentice AM, Coward WA. In vivo measurements of changes in body composition: description of methods and their validation against 12-d continuous whole-body calorimetry. American Journal of Clinical Nutrition 1993; 58 455-62.

100 Forbes GB, Simon W, Amatruda JM. Is bioimpedance a good predictor of body-composition change? American Journal of Clinical Nutrition 1992; 56: 4-6.

101 Macbeth H. Defining an ethnic group: important and impossible. In: Macbeth $\mathrm{H}$, Shetty $\mathrm{P}$, eds. Health and Ethnicity. London: Taylor and Francis, 2001, 1-20.

102 Bhopal R. Ethnicity and race as epidemiological variables: centrality of purpose and context. In: Macbeth H, Shetty P, eds. Health and Ethnicity. London: Taylor and Francis, 2001, 21-40

103 McKenzie K, Crowcroft NS. Describing race, ethnicity and culture in medical research. British Medical Journal 1996; 312: 1054 .

104 Anonymous. Style matters: ethnicity, race and culture; guidelines for research, audit and publication. British Medical Journal 1996; 312: 1094.

105 Wagner DR, Heyward VH. Measures of body composition in blacks and whites: a comparative review. American Journal of Clinical Nutrition 2000; 71: 1392-402

106 Ortiz O, Russell M, Daley TL, Baumgartner RN, Waki M, Lichtman S, Wang J, Pierson RNJ, Heymsfield SB. Differences in skeletal muscle and bone mineral mass 
between black and white females and their relevance to estimates of body composition. American Journal of Clinical Nutrition 1992; 55: 8-13.

107 Visser M, Gallagher D, Deurenberg P, Wang J, Pierson RNJ, Heymsfield SB. Density of fat-free body mass: relationship with race, age, and level of body fatness. American Journal of Physiology. 1997; 272: E781-7.

108 Werkman A, Deurenberg-Yap M, Schmidt G, Deurenberg P. A Comparison between Composition and Density of the Fat-Free Mass of Young Adult Singaporean Chinese and Dutch Caucasians. Annals of Nutrition and Metabolism 2000; 44: 235-42

109 Deurenberg-Yap M, Schmidt G, van Staveren WA, Hautvast JG, Deurenberg P. Body fat measurement among Singaporean Chinese, Malays and Indians: a comparative study using a four-compartment model and different twocompartment models. British Journal of Nutrition 2001; 85: 491-8

110 Norgan NG. The assessment of the body composition of populations. In: Davies PSW, Cole TJ, eds. Body Composition in Health and Disease. Cambridge: Cambridge University Press, 1995, 195-221.

111 Deurenberg P, Ge K, Hautvast JG, Wang J. BMI as predictor for body fat: comparison between Chinese and Dutch adult subjects. Asia Pacific Journal of Clinical Nutrition 1997; 6: $102-5$.

112 Deurenberg P, Yap M, van Staveren WA. Body mass index and percent body fat: a meta-analysis among different ethnic groups. International Journal of Obesity and Related Metabolic Disorders 1998; 22: 1164-71.

113 Wang J, Thornton JC, Russell M, Burastero S, Heymsfield S, Pierson RN. Asians have lower body mass index (BMI) but higher percent body fat than do whites: comparisons of anthropometric measurements. American Journal of Clinical Nutrition 1994; 60: 23-8.

114 Luke A, Durazo-Arvizu R, Rotimi C, Prewitt TE, Forrester T, Wilks R, Ogunbiyi OJ, Schoeller DA, McGee D, Cooper RS. Relation between body mass index and body fat in black population samples from Nigeria, Jamaica, and the United States. American Journal of Epidemiology 1997; 145: $620-8$.

115 Rush EC, Plank LD, Laulu MS, Robinson SM. Prediction of percentage body fat from anthropometric measurements: comparison of New Zealand European and Polynesian young women. American Journal of Clinical Nutrition 1997; 66: 2-7.

116 Gurrici S, Hartriyanti Y, Hautvast JG, Deurenberg P. Relationship between body fat and body mass index: differences between Indonesians and Dutch Caucasians. European Journal of Clinical Nutrition 1998; 52: 779-83.

117 Gurrici S, Hartriyanti Y, Hautvast JG, Deurenberg P. Differences in the relationship between body fat and body mass index between two different Indonesian ethnic groups: the effect of body build. European Journal of Clinical Nutrition 1999; 53: 468-72.

118 Gallagher D, Allen A, Wang Z, Heymsfield SB, Krasnow N. Smaller organ tissue mass in the elderly fails to explain lower resting metabolic rate. Annals of the New York Academy of Sciences 2000; 904: 449-55.

119 Kuriyan R, Petracchi C, Ferro-Luzzi A, Shetty PS, Kurpad AV. Validation of expedient methods for measuring body composition in Indian adults. Indian Journal of Medical Research 1998; 107: 37-45.

120 Deurenberg P, Deurenberg-Yap M, Wang J, Lin FP, Schmidt G. Prediction of percentage body fat from anthropometry and bioelectrical impedance in Singaporean and Beijing Chinese. Asia Pacific Journal of Clinical Nutrition 2000; 9: $93-8$.

121 Irwin ML, Ainsworth BE, Stolarczyk LM, Heyward VH. Predictive accuracy of skinfold equations for estimating body density of African-American women. Medicine and Science of Sports and Exercise 1998; 30: 1654-8.

122 Jackson AS, Pollock ML. Generalized equations for predicting body density of men. British Journal of Nutrition 1978; 40: 497-504.

123 Jackson AS, Pollock ML, Ward A. Generalized equations for predicting body density of women. Medicine and Science in Sports and Exercise 1980; 12: 175-82.

124 Brandon LJ. Comparison of existing skinfold equations for estimating body fat in African-American and white women. American Journal of Clinical Nutrition 1998; 67: $1155-61$.

125 Wong WW, Stuff JE, Butte NF, Smith EO, Ellis KJ. Estimation of body fat in Caucasian and African-American girls: total-body electrical conductivity methodology versus a four-component model. International Journal of Obesity and Related Metabolic Disorders 2000; 24: 1200-6.

126 Slaughter MH, Lohman TG, Boileau RA, Horswill CA, Stillman RJ, Van LM, Bemben DA. Skinfold equations for estimation of body fatness in children and youth. Human Biology 1988; 60: 709-23.

127 Wang J, Thornton JC, Kolesnik S, Pierson RN. Anthropometry in body composition. An overview. Annals of the New York Academy of Sciences 2000; 904: 317-26.

128 Stolarczyk LM, Heyward VH, Goodman JA, Grant DJ, Kessler KL, Kocina PS, Wilmerding V. Predictive accuracy of bioimpedance equations in estimating fat-free mass of Hispanic women. Medicine and Science of Sports Exercise 1995; 27: 1450-6.

129 Swinburn BA, Craig PL, Daniel R, Dent DP, Strauss BJ. Body composition differences between Polynesians and Caucasians assessed by bioelectrical impedance. International Journal of Obesity and Related Metabolic Disorders 1996; 20: 889-94.

130 Swinburn BA, Ley SJ, Carmichael HE, Plank LD. Body size and composition in Polynesians. International Journal of Obesity and Related Metabolic Disorders 1999; 23: 1178-83.

131 Heitmann BL, Swinburn BA, Carmichael H, Rowley K, Plank L, McDermott R, Leonard D, O'Dea K. Are there ethnic differences in the association between body weight and resistance, measured by bioelectrical impedance? International Journal of Obesity and Related Metabolic Disorders 1997; 21: 1085-92.

132 Morrison JA, Barton BA, Obarzanek E, Crawford PB, Guo SS, Schreiber GB. Racial differences in the sums of skinfolds and percentage of body fat estimated from impedance in black and white girls, 9 to 19 years of age: the National Heart, Lung, and Blood Institute Growth and Health Study. Obesity Research 2001; 9: $297-305$.

133 Jakicic JM, Wing RR, Lang W. Bioelectrical impedance analysis to assess body composition in obese adult women: the effect of ethnicity. International Journal of Obesity 1998; 22: 243-9.

134 Snijder MB, Kuyf BE, Deurenberg P. Effect of body build on the validity of predicted body fat from body mass index and bioelectrical impedance. Annals of Nutrition and Metabolism 1999; 43: 277-85.

135 Kushner RF. Bioelectrical impedance analysis: a review of principles and applications. Journal of the American College of Nutrition 1992; 11: 199-209.

136 Houtkooper LB, Going SB, Lohman TG, Roche AF, Van Loan MD. Bioelectrical impedance estimation of fat-free body mass in children and youth: a crossvalidation study. Journal of Applied Physiology 1992; 72 : 366-73.

137 Morrison JA, Guo SS, Specker B, Chumlea WC, Yanovski SZ, Yanovski JA. Assessing the body composition 
of 6-17-year-old Black and White girls in field studies. American Journal of Human Biology 2001; 13: $249-54$.

138 Williams DP, Going SB, Lohman TG, Hewitt MJ, Haber AE. Estimation of body fat from skinfold thicknesses in middle-aged and older men and women: a multiple component approach. American Journal of Human Biology 1992; 4: 595-605.

139 Baumgartner RN, Heymsfield SB, Lichtman S, Wang J, Pierson RNJ. Body composition in elderly people: effect of criterion estimates on predictive equations. American Journal of Clinical Nutrition 1991; 53: 1345-53.

140 Fuller NJ, Sawyer MB, Laskey MA, Paxton P, Elia M. Prediction of body composition in elderly men over 75 years of age. Annals of Human Biology 1996; 23: 127-47.

Appendix I Recommended field methods

\section{Young}

Skinfold equations

6-17 years, boys and girls, black and white (Slaughter et $a .^{126}$ )

BIA equations

6-10 years, boys and girls (Kushner ${ }^{135}$ )

8-15 years (Lohman ${ }^{1}$ )

10-19 years (Houtkooper et al. ${ }^{136}$ )

6-17 years, black and white girls (Morrison et al. ${ }^{137}$ )

\section{Adults}

Skinfold equations

Men and women (Durnin and Womersley ${ }^{80}$ )
Men (Jackson and Pollock ${ }^{122}$ )

Women (Jackson, Pollock and Ward ${ }^{123}$ )

BIA equations

Men and women (Segal et al. ${ }^{82}$ )

\section{Elderly}

Skinfold equations

$60-84$ years, men and women (Williams et al. ${ }^{138}$ ) These were not cross-validated

BIA equations

50-70 years, men and women (Lohman ${ }^{1}$ )

65-84 years, men and women (Baumgartner et al. ${ }^{139}$ )

Miscellaneous equations

$75+$ years, men (Fuller et al. ${ }^{140}$ )

\section{Ethnicity}

Population specific equations for converting body density to $\%$ fat and for estimating body composition from skinfolds and BIA in American Indians, blacks, whites, Hispanics and Asians are given by Heyward and Stolarczyk ${ }^{15}$.

Guidelines on choosing field methods are given by Lohman $^{1}$, Norgan ${ }^{110}$, Heyward and Stolarczyk ${ }^{15}$, Guo and Chumlea $^{79}$, and Heyward ${ }^{77}$. The estimation equations chosen should have been cross-validated and based on subjects with similar age, sex, ethnicity, levels of fatness and fitness to those of the population being investigated. 